\title{
THE HEALTH OF FORESTRY WORKERS : A SURVEY OF THE WOMEN'S TIMBER CORPS OF GREAT BRITAIN
}

BY

\author{
CATHERINE N. SWANSTON *
}

London

\section{Introduction}

In normal times Great Britain imports all but 4 per cent. of the timber needed for her industrial requirements, chiefly from Canada, Scandinavia and the Baltic States, and forestry work in this country is carried on by the Forestry Commission and private owners, who do research and reafforestation, and clean up woodland areas. War with Germany, however, resulted in a rapid and considerable drop in imports; the Baltic was closed, the Scandinavian countries were overrun and shipping could not be spared to bring large quantities of timber from Canada. At the same time there was a heavy demand at home. Timber was needed for army camps, for hostels, air stations, field telegraph poles, for beach landing runways, ammunition boxes and field hospitals, and at the same time essential civilian demands such as pit props and railway sleepers had to be met. In 1940, therefore, the Forestry Commission recruited a number of girls from the Women's Land Army to work in the woods and sawmills up and down the country, and in April 1942 the Women's Timber Corps was founded and became a working unit of the Home Timber Production Department of the Ministry of Supply. All the forestry girls working for the Forestry Commission were absorbed into the Corps and, in addition, many more were recruited from the Land Army.

\section{The Work of the Women's Timber Corps}

The Corps extends over England, Scotland and Wales, and at its zenith numbered nearly 6000 members. It may be apposite here to give some description of the work done by the girls. The major operations are felling, measuring, hauling out, stacking, loading and converting. This is the timber production work proper. In addition, there is saw bench work-mainly cutting small trees into pit props; and 'snedding'-hacking off the small branches from felled trees with a billhook or light axe. Trees destined for use as telegraph poles have also to be stripped of their bark, an operation known as 'peeling.' Finally, on some sites, the brushwood has to be cleared away and burnt.

* Recently Assistant Chief Medical Officer to the Ministry of Supply.

B
Horses and tractors are used for hauling timber away from the woods and the girls become adept at managing the one and driving the other; they also drive the heavily loaded lorries between the sites and the rail-heads and load the rail trucks themselves. Many girls work in sawmills, both in Government establishments and in private firms, and much of this work is arduous, as heavy timber is handled and considerable strength is required to lever the logs into position on the saw-bench. Here the girls often work with men and provided they are not put on to jobs which are too heavy for them, can maintain a good level of output. They learn to manipulate the different types of saws and some have apprenticed themselves to 'saw doctors' and learnt something of the art of setting saws.

In order that the nature of the work shall be properly appreciated it is necessary to describe in detail the chief timber production processes. The majority of girls are general forestry workers, that is, they do not work in sawmills, neither are they specialists, such as fellers or measurers. They are chiefly employed on cross-cutting or burning and clearing. Felling is probably the hardest operation of all. Fellers work in pairs and while there was great enthusiasm for this job at first, and there are still a number of excellent pairs of fellers in many parts of the country, the tendency has been for the girls to drop off felling or for the foreman to take them off because of their low output, and for them to concentrate more on cross-cutting and stacking, or clearing and burning, specially in those areas where the stands of timber are not easy. The job itself consists of two processes: 'laying-in' or ' rounding up' which is axeing a wedge out of the base of the trunk so that the tree shall fall properly, and cross-cutting with a two-handled saw through the trunk at the apex of the wedge. A woodman's axe weighs $7 \mathrm{lb}$. and when hard timber is being felled, the process of laying-in is the hardest part of all as the axe must be swung with considerable vigour. After the tree has been felled and snedded, and the trunk peeled, if this is required, it is then hauled out of the wood and either loaded on to a pole wagon as a complete tree or sawn off into lengths at the saw-bench and stacked or loaded into lorries. The saw-bench is trying work as the trunk 
FIG. 1.-Felling. The axe strokes mark the way the tree will fall.

FIG. 2. - Sawbench. Cutting the logs.

FIG. 3.-Sawing t i m ber to lengths for pit props.
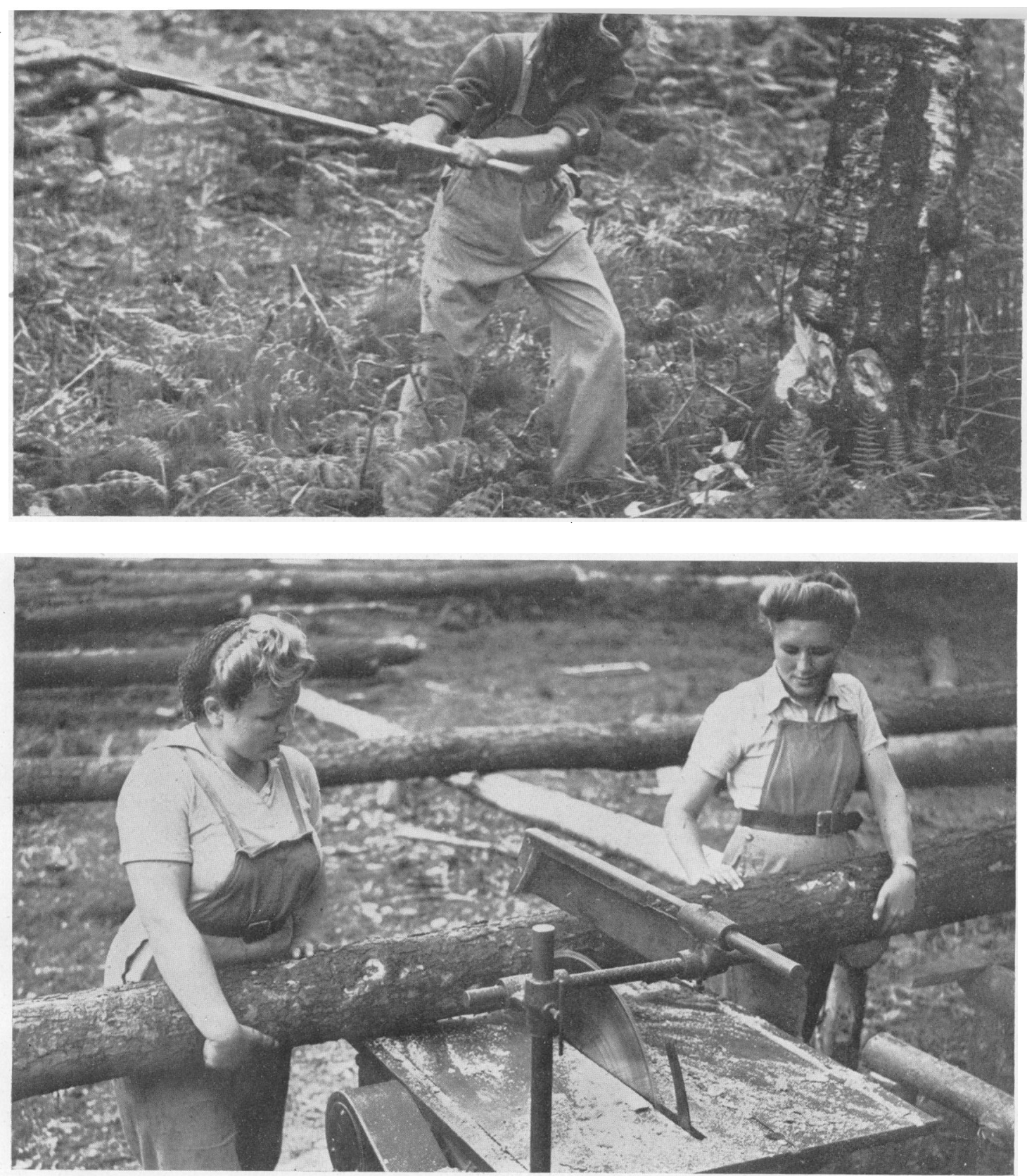

$x^{2}$

$150 x^{2}=4$

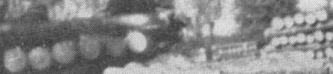

troperas

yomes?

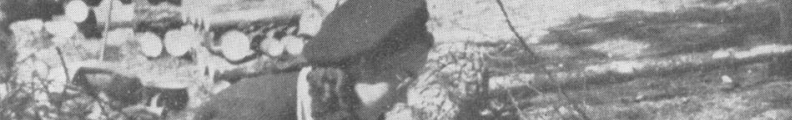

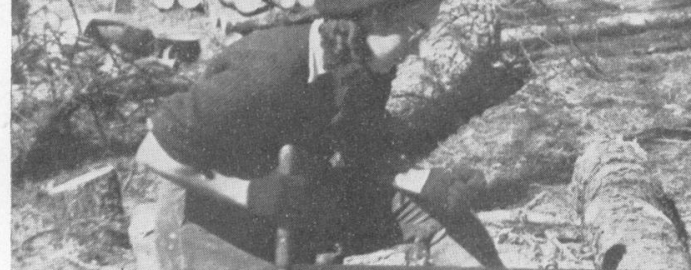

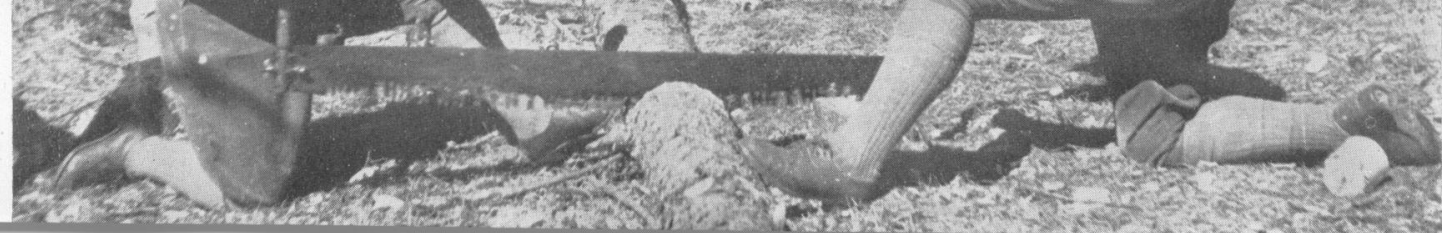


has to be lifted on to the bench and held in position during sawing. The circular saws used for this operation are often somewhat haphazardly guarded, yet serious accidents are unknown. Stacking of pit props and sleepers, some of which weigh $60 \mathrm{lb}$. and all of which are awkward loads, is hard and tiring work and this also applies to the loading of lorries and railway trucks. The girls work in small groups under the supervision of a 'ganger,' who in her turn is responsible to the foreman or forewoman of the site. On some sites men do the heavy hauling and felling, and much of the work done by the girls is felling conifers (soft wood) for use as telegraph poles and pit props. This gives an indication of the size of the trees handled in the woods.

A certain number of girls are employed as measurers, whose job is to measure the felled timber and to calculate the amount of available wood in each tree. They also survey new woods and mark off trees suitable for felling. This job is slightly better paid than general forestry work, special training is needed and intelligent girls with some mathematical ability are usually chosen. This work is not heavy except in so far as the measurer may be asked to give a hand in hauling timber, but it is often lonely as many of them work singly or in pairs on sites which have been completely felled and from which all the other workers have left.

\section{Working and Living Conditions}

The working environment of the Timber Corps is made up of the fields and woods of the countryside, and while certain things can be done to increase the comfort of the civilized individual working in natural surroundings, the all-important factor on this job is the weather. Conditions vary from ideal in summer (except when it is very hot) to almost unbearable in winter, and during the cold spells of last winter (1944-45) many of the timber camps (especially in Scotland) were completely snowed up. Lorries could not be got on to the roads to take the girls to work and at one camp food had to be fetched several miles by an improvised horse-sleigh. Working sites are provided with wooden huts, usually of the movable type, which can be heated by a stove and in which the girls can shelter during the rain. The girls themselves wear uniform similar to that of the Land Army and work in breeches, dungarees or, in the hot weather, shorts.

They live in hutted camps built specially for the Corps and accommodating 20-50 girls in each; in private houses which have been requisitioned for use as small hostels; in the large hostels attached to the Royal Ordnance Factories, where they form a small unit among the other industrial workers; and in selected private billets. In Scotland, camps and small hostels predominate owing to the isolated working sites and the difficulty in finding billets, but in England and Wales, where billets are much more plentiful, the majority of girls live in these. On the whole camps are more popular than billets and they possess certain obvious advantages, such as the provision of adequate means for drying wet clothes and proper sick-bay arrangements for looking after girls who are ill. Many of the girls themselves are trained in first aid and minor injuries at work are treated on the site with the aid of a first-aid box.

\section{Medical Survey of a Group of Workers in the Corps}

During the summer of 1945 a survey was undertaken to try to find out what harmful effects, if any, were likely to be produced in women by forestry work. A certain uneasiness had been evinced by Production and Welfare Officers * in different parts of the country on account of the rising sickness rate among members of the Corps. In some places production was being seriously affected and there was a growing impression that many of the girls were beginning to feel the strain of several years in the woods and sawmills. It appeared that this high sickness rate was largely influenced by three factors:

(1) The prevalence of locomotor diseases, particularly muscular rheumatism.

(2) Gastro-intestinal complaints.

(3) An increasing amount of menstrual sickness. Special attention was therefore paid to these points during the interviews and examinations which made up the survey.

One hundred and sixty-one girls were seen in all parts of the country and as the investigation took place in the weeks immediately following a widespread heat-wave the girls were seen under ideal conditions, and most of them looked extremely fit and sunburned. Owing to the difficulty of carrying out examinations in private houses the majority of those interviewed were camp or hostel residents, and only 30 billeted girls were seen, all in England and Wales.

It was considered desirable that all examinations should be voluntary as it was necessary to gain the confidence and co-operation of the girls. There was no lack of volunteers, in fact it was sometimes impossible to examine all who offered. Every forestry and sawmill job was represented, the largest groups being fellers (50), saw mill and saw-bench workers (27) and measurers (16). The length of service in the Corps-including previous service in the Forestry Commission, but not in the Women's Land Army-varied from under two to over four years, with the greatest number (87) in the 2-3 year group. In assessing the information obtained, therefore, it must be borne in mind that because the group was made up of volunteers, it may not be a representative sample.

The age groups were as follows: 19 years, 19; 20-24 years, $100 ; 25-29$ years, $29 ; 30-34$ years, 12 ; 35-39 years, 1 ; i.e. a total of 161 .

The lower age limit for joining the Corps is 17 and many girls do in fact enter at this early age.

* The Women's Timber Corps is divided, geographically, into nine areas or Divisions for administrative purposes, each with its own Production and Welfare Officers. 


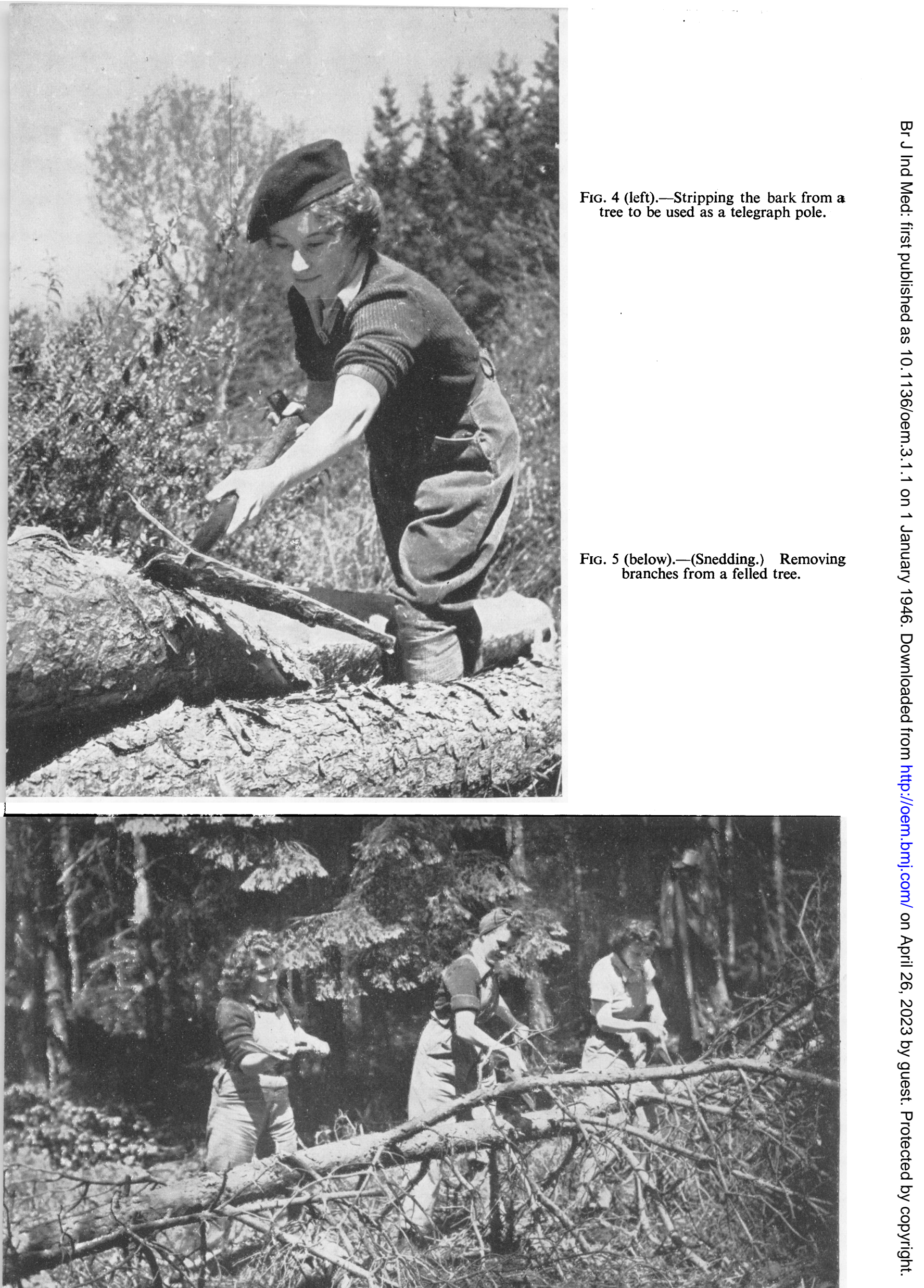


They are recruited through the Land Army, but all recruitment ceased in September 1943 which, perhaps, accounts for the large number of 20-24-yearolds.

\section{Medical Examination}

1. Interview. A careful history was taken which included a detailed working history since entry into the Corps, with a note of the girl's previous occupation. Most of the girls were town bred, many from the great industrial cities of the North and Midlands and in Scotland from Glasgow and Edinburgh, and while the majority came from factories a wide variety of occupations was represented, including shop assistants, hairdressers, children's nurses, clerks and switchboard operators. With a few exceptions they enjoyed the Timber Corps and felt the open-air life had done them good. Many said that they did not want to return to their old jobs in factories or offices, but would prefer to continue on the land.

Only a proportion of girls had received a medical examination on entry, and in many cases this was little more than a formality. No records had been kept of these examinations, and there were therefore no basic data concerning the physical condition of these girls when they started forestry work for comparison with their state of health at the time of this survey.

Details of past illnesses were noted and those occurring since entry into the Corps were later checked against sickness records, and special attention was paid to eliciting information of gastrointestinal disturbances, menstrual dysfunction and the occurrence of rheumatism, fibrositis and myalgia. Every girl was asked whether she had lost or gained weight since she entered the Corps, whether she was feeling fit or beginning to get tired, and whether she had contemplated leaving on account of health reasons. All girls presenting themselves for examination had been asked to be weighed and measured during the previous week and this had been done in most cases.

2. Physical Examination. The physical examination following the interview comprised an appraisal of the general physique, inspection of mouth and throat, examination of the heart, lungs and abdomen and measurement of blood pressure. In a few cases urinalyses and exercise tolerance tests were done. A rough estimation of the haemoglobin level by the Tallquist method was also done on every girl. It is realized that this is not an accurate evaluation, but it was the only possible method for this survey as many of the examinations had to be carried out under somewhat primitive conditions.

\section{General Physical Standard}

In general the physique of the girls was good and in a number it was really excellent. In many of those engaged on felling or other heavy jobs there was a marked development of the muscles of the shoulder girdle, upper chest wall and arms, the pectoral and deltoid muscles in particular being hypertrophied. The girls looked well, with clear eyes and skin, and many of them were deeply tanned through working during the hot weather in a minimum of clothing. They were alert, high spirited and 'full of beans.' The physical examination itself revealed nothing abnormal in the great majority. Twenty-six girls showed a mild degree of anaemia ( $\mathrm{Hb} 70$ per cent. or under-Tallquist) and there were a good many complaints of constipation due possibly to too much starchy food (the daily lunch is eaten in the woods and consists of sandwiches washed down by quantities of tea) and lack of lavatory facilities on the working sites. Only occasionally was dental caries found; most girls took good care of their teeth and paid fairly regular visits to their dentists.

TABLE 1

AGE/WEIGHT GROUPS

\begin{tabular}{|c|c|c|c|c|}
\hline Age groups & $\begin{array}{l}\text { Normal } \\
\text { weight }\end{array}$ & $\begin{array}{l}\text { Over- } \\
\text { weight }\end{array}$ & $\begin{array}{l}\text { Under- } \\
\text { weight }\end{array}$ & Total \\
\hline $\begin{array}{r}-19 \text { years } \\
20-24 \text { years } \\
25-29 \text { years } \\
30-34 \text { years } \\
35-39 \text { years }\end{array}$ & $\begin{array}{r}3 \\
20 \\
5 \\
3 \\
-\end{array}$ & $\begin{array}{r}12 \\
56 \\
14 \\
4 \\
-\end{array}$ & $\begin{array}{r}4 \\
20 \\
8 \\
5 \\
1\end{array}$ & $\begin{array}{r}19 \\
96 \\
27 \\
12 \\
1\end{array}$ \\
\hline Total & 31 & 86 & 38 & 155 \\
\hline
\end{tabular}

Using standard height/weight/age tables * for comparison it was found that 38 girls out of 155 weighed were underweight, 86 were overweight and 31 were within normal limits. The group of overweights need not be considered further; very few cases of obesity were found and the increase was generally of the order of a few pounds and could be accounted for by increased physical development. The underweights showed variations from a few pounds to over 2 stone and included in this group was a number of girls suffering from definite pathological conditions such as chronic bronchitis, spinal scoliosis and general debility. In the older age groups, that is from 25 onwards, there was a higher proportion of girls underweight than in the 19-24 group - 33 per cent. as against 20 per cent.-and a higher proportion of those who had ' had enough' and wanted their release from the Corps. Similarly the underweights as a group showed a much higher proportion of those who wanted to leave than the others. The chief reason given was increasing fatigue.

TABLE 2

COMPLAINTS OF FATIGUE IN RELATION TO WEIGHT

\begin{tabular}{|c|c|c|c|}
\hline & Total & Fatigue & Per cent. \\
\hline $\begin{array}{cr}\text { Normal or } & \text { over- } \\
\text { weight } & \ldots \\
\text { Underweight } & \ldots\end{array}$ & $\begin{array}{r}117 \\
38\end{array}$ & $\begin{array}{l}15 \\
13\end{array}$ & $\begin{array}{l}13 \\
34\end{array}$ \\
\hline Total .. & 155 & 28 & 18 \\
\hline
\end{tabular}

* From the American L.ife Extension Institute. 
FIG. 6 (right).-Pit props, sawn to length, are stacked for transport. Three girls carrying a prop to the stack. (Weight of $\log$ is about $156 \mathrm{lb}$.)

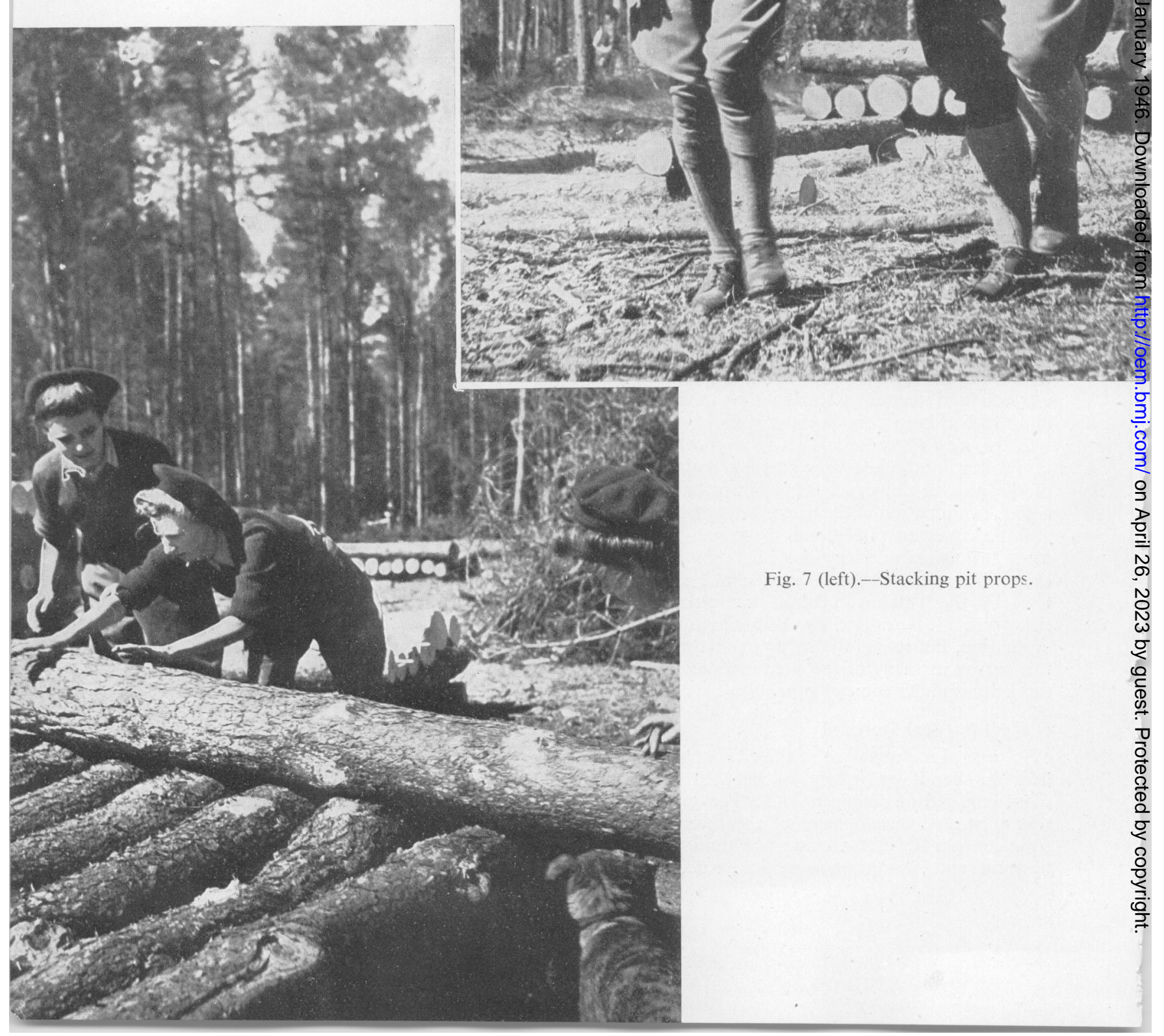


TABLE 3

\section{COMPLAINTS OF FATIGUE IN RELATION TO AGE GROUPS}

\begin{tabular}{cc|c|c|c}
\hline Age groups & & Total & Fatigue & Per cent. \\
\hline 19 years & $\ldots$ & 19 & 1 & 10 \\
20-24 years & $\ldots$ & 100 & 12 & 12 \\
25-29 years &. & 29 & 7 & 25 \\
30-34 years &. & 12 & 7 & 55 \\
35-39 years &. & 1 & - & - \\
\hline Total .. &. & 161 & 27 & 17 \\
\hline
\end{tabular}

It was found that complaints of fatigue increased with length of service up to a maximum for those who had been in the Corps over three but under four years. After 4 years of service a slight decline was observed.

TABLE 4

\section{COMPLAINTS OF FATIGUE IN RELATION TO LENGTH OF SERVICE}

\begin{tabular}{|c|c|c|c|c|}
\hline \multicolumn{2}{|c|}{ Length of service } & Total & Fatigue & Per cent. \\
\hline $\begin{array}{l}-2 \text { years } \\
2-3 \text { years } \\
3-4 \text { years } \\
\text { Over } 4 \text { years }\end{array}$ & $\begin{array}{l}\ddot{.} \\
\ddot{*} \\
\cdots\end{array}$ & $\begin{array}{l}25 \\
88 \\
30 \\
18\end{array}$ & $\begin{array}{r}1 \\
14 \\
9 \\
4\end{array}$ & $\begin{array}{r}4 \\
17 \\
30 \\
22\end{array}$ \\
\hline Total ... & . & 161 & 28 & 17 \\
\hline
\end{tabular}

In computing these figures no attention was paid to compassionate reasons for release, physical grounds only being taken into consideration. Of the 38 underweights 21 had lost weight during their service in the Corps, and while many of them were thin and weedy with poor muscular development, this group included two of the healthiest girls seen.

\section{Certified Sickness}

Records were obtained for the 161 girls seen in the areas visited for the year ending June 30, 1945. One hundred and twenty-one girls had been off work due to certified sickness and had lost between them 3242 days, an average of 20 days lost over the whole group. This does not include lost time owing to works accidents.

The chief causes of sickness were gastro-intestinal complaints (12.3 per cent.), locomotor diseases (17.4 per cent.) and surgical conditions (26.7 per cent.). The last group included 5 cases of appendicitis who lost between them 425 days, which represents half the total for this group. Influenza, colds and respiratory conditions accounted for 13.4 per cent. and nervous conditions 7.7 per cent. The full analysis is given in Table 5 .

\section{Medical Discharges}

The medical discharges in the Divisions visited numbered 323 over the same period (Table 6). This is 40 per cent. of all releases from those areas. It will be seen from the following analysis that the chief reasons given were respiratory, locomotor complaints (rheumatism) and debility. The after effects of accidents at work also accounted for a sizeable fraction and pregnancy for nearly 20 per

TABLE 5

SICKNESS ANALYSIS

\begin{tabular}{c|l|c|r|c}
\hline Group & \multicolumn{1}{|c|}{ Disease } & $\begin{array}{c}\text { Total } \\
\text { days } \\
\text { lost }\end{array}$ & $\begin{array}{c}\text { Per cent. } \\
\text { of total } \\
\text { absence }\end{array}$ & $\begin{array}{c}\text { Days } \\
\text { lost per } \\
\text { person }\end{array}$ \\
\hline 1 & Influenza, colds & 185 & $5 \cdot 8$ & $1 \cdot 1$ \\
2 & Respiratory & 246 & $7 \cdot 6$ & $1 \cdot 5$ \\
3 & Cardio-vascular & 104 & $3 \cdot 3$ & $0 \cdot 6$ \\
4 & Gastro-intestinal & 396 & $12 \cdot 3$ & $2 \cdot 5$ \\
5 & Nervous.. & 250 & $7 \cdot 7$ & $1 \cdot 6$ \\
$6 a$ & Skin, general & 36 & $1 \cdot 0$ & $0 \cdot 2$ \\
$b$ & Skin infestation & 164 & $5 \cdot 0$ & $1 \cdot 0$ \\
7 & Locomotor .. & 564 & $17 \cdot 4$ & $3 \cdot 5$ \\
8 & Surgical.. & $865 *$ & $26 \cdot 7$ & $5 \cdot 3$ \\
9 & Infectious fevers & 13 & $0 \cdot 4$ & $0 \cdot 1$ \\
10 & Gynaecological & 82 & $2 \cdot 5$ & $0 \cdot 5$ \\
11 & Anaemia & 33 & $1 \cdot 0$ & $0 \cdot 2$ \\
12 & Varicose veins .. & 24 & $0 \cdot 7$ & $0 \cdot 2$ \\
13 & Various & 280 & $8 \cdot 6$ & $1 \cdot 7$ \\
\hline Total & & 3242 & $100 \cdot 0$ & $20 \cdot 0$ \\
\hline
\end{tabular}

* Includes 5 cases of appendicitis who lost together 425 days.

TABLE 6

DISCHARGES FOR MEDICAL REASONS

\begin{tabular}{|c|c|c|c|c|}
\hline \multicolumn{3}{|c|}{ Diagnosis } & Number & $\begin{array}{c}\text { Percentage } \\
\text { of total }\end{array}$ \\
\hline $\begin{array}{l}\text { Respiratory } \\
\text { Cardio-vascular } \\
\text { Gastro-intestinal } \\
\text { Nervous debility } \\
\text { Skin conditions } \\
\text { Locomotor } \\
\text { Gynaecological } \\
\text { Accidents at work } \\
\text { Anaemia . . } \\
\text { Varicose veins } \\
\text { Pregnancy .. } \\
\text { Surgical . . } \\
\text { Various . . }\end{array}$ & $\begin{array}{l}\cdots \\
\cdots \\
\cdots \\
\cdots \\
\cdots \\
\cdots \\
\cdots \\
\cdots \\
\cdots \\
\cdots \\
\cdots\end{array}$ & $\begin{array}{l}\ldots \\
\ldots \\
\cdots \\
\cdots \\
\cdots \\
\cdots \\
\cdots \\
\cdots \\
\cdots \\
\cdots\end{array}$ & $\begin{array}{r}37 \\
4 \\
16 \\
68 \\
8 \\
56 \\
4 \\
46^{5 *} \\
7 \\
4 \\
62 \\
12 \\
19\end{array}$ & $\begin{array}{r}11 \cdot 0 \\
1 \cdot 2 \\
4 \cdot 4 \\
21 \cdot 0 \\
2 \cdot 4 \\
17 \cdot 0 \\
1 \cdot 2 \\
8 \cdot 3 \\
2 \cdot 3 \\
1 \cdot 2 \\
19 \cdot 9 \\
3 \cdot 4 \\
6 \cdot 7\end{array}$ \\
\hline Total .. & . & . & 323 & $100 \cdot 0$ \\
\hline
\end{tabular}

* Raised figures indicate cases of strains and sprains.

cent. While this is too small a group to be of statistical value, these figures are interesting, in that they show a high sickness rate and a high discharge rate in a selected group of young women doing rather specialized work. In their interpretation certain points should be borne in mind.

In the first place forestry work is all hard work, with the exception of measurers whose work generally is lighter, and cannot be done by the girl who is convalescent after an illness or who needs a ' light' job. There is no alternative work on the timber site or in the sawmill, and the girl who has 
been off sick needs to be pretty fit before she can come back to work at all. This doubtless prolongs each spell of sickness. Secondly, a medical release is often the easiest way of leaving the Corps in the absence of strong compassionate grounds. On the other hand, forestry workers are chiefly in the younger age groups and are not, except in very few cases, saddled with domestic duties or have long journeys to and from work. They are living a healthy life, and the great majority are being well fed and looked after in camps or carefully chosen billets.

\section{Gynaecological Conditions}

Menstrual irregularities are known to result from a change in living conditions or from taking up different work, specially if the latter is physically exacting. In this survey 37 girls said that their menstrual periods had got worse since they took up forestry work, the chief complaints being increased pain (20), increased bleeding (17) and irregular or more frequent periods (10). Ten of this group said they only had trouble if they were on particularly heavy work-felling was the chief process mentioned. On the other hand, 15 girls said that they had less pain, and 3 that they had been more regular since they entered the Corps. It is not possible to assess the exact amount of time lost through menstrual dysfunction as many odd days off are not recorded, but it is unlikely that this is a great deal as only 33 girls stated they took time off and of these the majority only occasionally. It is generally recognized that heavy work may produce dysmenorrhoea and menorrhagia, and therefore a certain amount of time lost among these girls is to be expected. Sickness records for the group show only a proportion of 2.5 per cent. for certified sickness due to gynaecological causes, and this is no higher than that found in other industrial groups. Again, out of 323 discharges only 4 were due to gynaecological conditions and throughout this survey not one case was encountered sufficiently serious to warrant a recommendation for release.

\section{Locomotor Diseases, including Rheumatism}

$17 \cdot 4$ per cent. of all time lost through certified sickness was due to locomotor conditions, chiefly rheumatism. This is more than double the proportion lost by women in the Royal Ordnance Factories. Very few of these girls gave any history of a rheumatic diathesis, but a good many said that they often had muscular limb pains during wet weather. Rheumatism, fibrositis, myalgia and neuritis may almost be said to assume an occupational significance in relation to forestry work. The high incidence is, no doubt, occasioned by the unavoidable working conditions in wet and cold weather, by travelling home in wet clothes and the difficulties of thorough drying in billets.

Apart from rheumatism itself, a good deal of time was lost and a good many girls discharged through traumatic strains and sprains. The time lost has been omitted from the certified sickness analysis, but in the records received, they account for 462 days lost at least in the group of 161 girls over one year. Of 26 girls who were discharged on account of disabilities arising from accidents at work 17 were suffering from strained muscles.

\section{Gastro-intestinal Complaints}

Dyspepsia and gastritis accounted for most of the time lost in this group. The relatively high proportion (12.3 per cent.) might be influenced by the daily sandwich lunch, the bulk of which is often eaten during the mid-morning break and there is a subsequent long period without food until the evening meal. It appeared, too, that a good many girls ate an excess of starchy foods, which might give rise to a carbohydrate dyspepsia. Very few girls complained of severe digestive disturbances, and none showed any signs of serious trouble.

\section{Discussion}

The information gained in this survey provides conflicting evidence in respect of the health of these girls. At the interviews, they were on the whole a healthy, cheerful and contented group, many of them looking extremely fit. The subsequent physical examinations produced little to counteract this impression, and without going further, it would not have been unreasonable to give them a clean bill of health and assume that there was no cause for uneasiness. But investigation of the sickness absence of the group told a very different tale. Seventy-five per cent. were absent during the period under review, a high proportion, and between them lost 3242 working days, an average of 26 days each or 20 days for the whole group. Forestry work is strenuous and to the stresses of the job itself are added the trials of damp and cold. Much of the work requires a sustained physical effort and good muscles and strong limbs are needed. Though they speak well of the ability of the girls to tackle and master the different operations, Production Officers have told me that two good hard-working girls can do no more than equal one man's output, and I have heard the ratio put as low as four to one when the girls are becoming tired. This discrepancy in output is not surprising when it is remembered that a woman's physical strength is only about half that of a man. Many girls underwent a period of training on first joining the Corps, but in any future training courses stress should be laid on the correct methods of lifting and carrying weights. Failure to do this will inevitably result in a high incidence of strains and sprains.

Forestry girls are probably less subject to the stresses and strains of war-time existence than any other industrial group. They are away from home it is true, but they are mainly in safe country districts (an exception must be made for those girls in south-east England during the flying-bomb era) and they have no household duties when they get back from work. Yet each area shows a lengthy list of discharges on medical grounds of girls who have failed to stay the course. The Corps at 
present represents the survival of the fittest, and in the small group which made up this survey there were a number who complained of increasing fatigue and who viewed with some alarm the prospect of spending another winter in the woods. An occupation which gives rise to so much general sickness cannot be considered altogether suitable or satisfactory work for women. When their relatively low level of output is also taken into consideration it becomes doubtful, apart from any risk to health, whether the employment of women in forestry work can be economically justified. Nevertheless they might be needed in some future crisis, and the following suggestions are put forward for consideration should any re-establishment of the Corps become necessary :

1. The age limits of entry should be $20-30$ years. Exceptions might be made in the case of women over 30 who are used to strenuous open-air work.

2. Girls should be medically examined before acceptance by doctors who are familiar with the hazards of the job. During this war several instances have arisen of girls being recommended for timber work because it was considered that they required an open-air life.

3. A half-yearly medical check-up should be compulsory during service in the Corps.

4. Particular attention should be paid to the provision of proper clothing, including waterproof and windproof garments for winter wear of a suitable type.

5. Camps should be provided in preference to billets and proper means for drying clothes should be realized.

6. Good covered transport should be provided to and from working sites and each site should be provided with a hut or shelter which is waterproof and can be heated.

7. Mobile canteens capable of delivering hot meals and hot drinks to the working sites would do much to maintain a proper standard of nutrition and reduce the incidence of digestive complaints. A full hour should be allowed for the mid-day meal.

8. All recruits should receive an initial period of training which should include the teaching of proper methods of handling heavy timber.

\section{Summary}

During the summer of 1945 a survey was undertaken of a group of girls employed in the Women's Timber Corps to try and determine what effects, if any, forestry work produces in women.

A hundred and sixty-one girls were interviewed and physically examined. Of these 30 lived in private billets, and 131 in camps and hostels. Every type of forestry work done by women was represented, including sawmills, and many different parts of the country were visited.

The general health at the time of examination was found to be good in most cases. Thirty-eight were underweight and 28 wished to leave the Corps for health reasons, chiefly fatigue. The loss of weight and tiredness were commoner among those over 25 years of age.

The sickness rate for the group averaged 20 days lost by each worker. Of this, one-sixth was due to locomotor diseases, chiefly rheumatism.

Discharges on medical grounds accounted for $40 \mathrm{per}$ cent. of all releases in the areas visited over a period of one year. Of these one-sixth were on account of rheumatism and locomotor diseases, and 26 girls were released because of the after effects of accidents at work.

Gynaecological complaints accounted for no more lost time than would be found in any other group of industrial workers. Thirty-seven girls ( 23 per cent.) gave a history of menstrual irregularities of some sort and 33 girls ( 20 per cent.) took occasional days off, and these occasional conditions accounted for only 4 out of 323 medical discharges.

There is apparently a high incidence of muscular strains and sprains in the group and these formed the majority of lost-time accidents.

It is considered that the employment of women in forestry work is not normally justifiable on account of their high sickness rate and comparatively low level of output, but in the event of it becoming necessary ever to re-form the Women's Timber Corps, certain suggestions have been put forward for safeguarding the health of its members.

\section{Acknowledgments}

For help in this work I am indebted to the Home Timber Production Department of the Ministry of Supply, in particular to Miss M. E. Hoskyn the Chief Officer, and the Divisional Welfare Officers of the Women's Timber Corps who co-operated in the survey. I also have to thank Dr. A. J. Amor, Chief Medical Officer of the Ministry, for permission to publish this report.

I have also to acknowledge with thanks permission to reproduce the photographs as follows: figs. 1 and 9, from Illustrated Leicester Journal; figs. 2 and 5, from Sport and General; figs. 3, 4, 6, and 7, from Ministry of Information; and fig. 8, from Planet News, Ltd. 